\title{
Sarawak Peat Characteristics and Heat Treatment
}

\author{
N. M. Sa'don, A. R. Abdul Karim, W. Jaol and W. H. Wan Lili \\ Faculty of Engineering, Universiti Malaysia Sarawak, Sarawak, MALAYSIA \\ Date Received: 7 November 2014 \\ Date Published: 30 January 2015
}

\begin{abstract}
Peat layer is extensively scattered over the land of Malaysia. In Sarawak alone, peatland represents 13 percent (about 1.66 million hectares) of Sarawak's total land area. They are present, mostly in low-lying areas; with in some areas, peat exceeding $10 \mathrm{~m}$ in depth. During past few decades, the demands on development of land were expanded into the swamp and deep peat areas which cannot be avoided. Thus proper management and construction practices should be emphasized, in order to overcome consequential occurrence of ground subsidence problems. The objectives of this study are to determine the characteristics of Sarawak peat, their empirical correlations as well as the effect of heat treatment on peat. The samples were taken from Matang, Batu Kawa, and Kota Samarahan sites, in Sarawak. The characteristic tests consist of degree of humidification, loss on ignition, Atterberg limit, particle density, moisture content and $\mathrm{pH}$ value. The results recorded high moisture content and organic content of Sarawak peat. It is also being categorized under the hemic group with $\mathrm{pH}$ values ranging from 3 to 4 . The heat treatments with temperatures ranging from $100^{\circ} \mathrm{C}$ to $400^{\circ} \mathrm{C}$ were used on the peat samples. Samples collected were undergoing heat treatment and changes to its physical characteristic were compared with the original Sarawak peat. It was found that the heat treatments do influence the physical properties of Sarawak peat and have shown significant reduction in the compression index determined through the empirical correlations.
\end{abstract}

Keywords: Sarawak peat, heat treatment, degree of humidification loss of ignition.

\section{INTRODUCTION}

$\mathrm{P}$ EAT is defined as highly organic soil with the heterogeneous mixture of partially decomposed plant remains, with some contents of sand, silt and clay under damp and anaerobic condition. Obviously, the content of organic remains in peat is sufficiently fresh and undisturbed to permit identification of plant remains whose structure ranges from more or less decomposed plant remained to a fine amorphic mass. Approximately 1.7 million ha (13\%) of the Sarawak State's total land area, are covered with peat [1]. This peat land is located in the primal lowlands and along the coast, usually situated 2 to $4 \mathrm{~km}$ inward. Most of Sarawak's peat lands are found in the central region of the State, specifically in Sibu Division, which roughly covers 70 percent of the division (refer Figure 1).

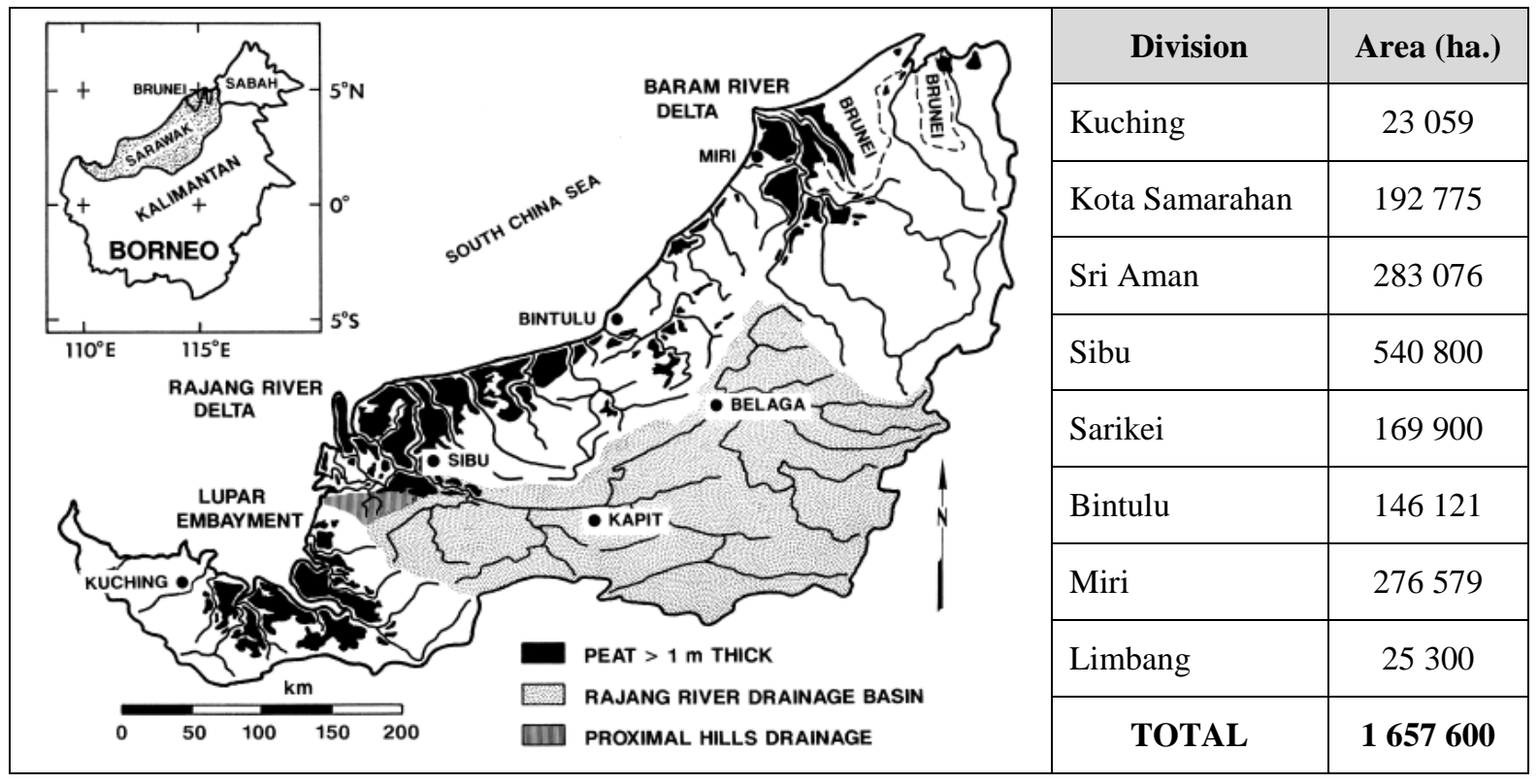

Figure 1 The distribution of peat in Sarawak [2] 
Peat present mostly in surface soils where the water table is near or above the ground surface but in some cases as deep deposits. The overall hydrological characteristic depends upon the rainfall and the surface topography. High moisture content in peat is the main factor contributing to the characterization of peat with low bearing capacity and bulk density. Due to this, peat is incapable of carrying excessive weight. The consequences for engineering structures on peat resulting from the high and rapid compressibility are often very serious [3]. A study performed in Sibu town by [4] shows that the removal of water by drainage leading to the bulging of peat near roads and caused ground settlement due to their poor mechanical performance.

In general, about 90 percent of peat in Sarawak is classified as deep peat (depth of more than 1.5 meter). The depth of peat layer increases from the coast towards the inlands. According to [5], field investigation conducted in Western Sarawak has proven that there are three significant layers differentiated by its level of humidification based on the Von Post classification system, where each layer overlain the subsequent layer. The top thin layer of $0.5 \mathrm{~m}$ to $1.5 \mathrm{~m}$ thick is recognized as sapric (H7-H10) peat with fiber content of less than 33 percent. The second layer of peat, overlain by sapric peat, is recognized as hemic peat (H4-H6) with fiber content ranging from 33 to 66 percent. The near beneath of peat soil layer, overlain by hemic peat, is recognized as fibric peat (H1-H3) with fiber content of greater than 66 percent, and a layer of grey mangrove clay may be likely to be seen under the fibric layers. The content of peat differs from location to location due to the factor such as origin fiber, temperature and humidity [6].

Further, peats are well known for their high compressibility and long term settlement. From previous study stated that, the majority of settlement is results from creep at constant vertical stress. Typically, increase in temperature causes an increase in pore water pressures and soil compressibility with the opposite behavior upon cooling. The thermal precompression method accelerates the pre-loading process for organic soil [7]. The laboratory tests performed by [8] indicated that moderate heating $\left(15^{\circ} \mathrm{C}\right.$ to $\left.40^{\circ} \mathrm{C}\right)$ accelerates settlement of peat significantly and further long-term settlement is greatly reduced upon cooling. This method is subsequently was evaluated in the field and indicated that it could provide time savings over conventional stress-induced pre-loading, reduce stability issues associated with surcharging and offer a means of reducing the secondary compression of peats [9]. In summary, peat is problematic material; hence suitable geotechnical parameters and construction techniques are needed for this type of ground condition. This paper presents the findings on geotechnical characteristics and their empirical correlations for Sarawak peat and the influence of heat treatment, which has been performed in Geotechnical Laboratory, UNIMAS. All the experimental investigations were performed in accordance to [10] unless stated otherwise.

\section{SARAWAK PEAT}

\section{- Properties of Sarawak Peat}

Table 1 presents the basic geotechnical properties of Sarawak peat. The samples were categorized into the hemic group, ranging from $\mathrm{H} 4$ to $\mathrm{H} 5$ according to the Von Post classification system. The description suited the classification made as the samples were slightly decomposed and a very small amount of granular peat with muddy dark water escaped between the fingers upon squeezing. Organic content in Sarawak peat is best determined by performing loss on ignition test. From the test, one can be seen that the organic content for Sarawak peat is very high, which varies from $89 \%$ to $95 \%$. Further, higher percentage of organic matter produced relatively high moisture content of Sarawak peat. Based on the published work, it has been proven indeed reasonable that the voids between organic particles have a high capacity of entrapping moisture content, which resulted in high moisture content of peat. It is clearly shown that, the organic content does affect the moisture content of Sarawak peat. Batu Kawa's samples have shown relatively high organic content, which also resulted in high moisture content records (refer Table 1). The $\mathrm{pH}$ value for Sarawak peat falls in the range of 3 to 4, which is classified as acidic and the $\mathrm{pH}$ values increases with decreasing organic content.

Table 1 Geotechnical Properties of Sarawak Peat

\begin{tabular}{|l|c|c|c|}
\hline \multirow{2}{*}{ Location } & \multicolumn{3}{|c|}{ Sarawak Peat } \\
\cline { 2 - 4 } & Matang & Batu Kawa & Kota Samarahan \\
\hline Von Post Classification & H4 - H5 (Hemic) & H5 (Hemic) & H4 (Hemic) \\
\hline Moisture Content $\left(w_{N}\right)(\%)$ & $594-856$ & $607-926$ & $426-817$ \\
\hline Liquid Limit, LL $(\%)$ & $234-245$ & $252-261$ & $192-200$ \\
\hline Plasticity Index, PI $(\%)$ & 81 & $97-100$ & $95-110$ \\
\hline Organic Content, OC $(\%)$ & 95 & 95 & 89 \\
\hline Fiber Content, FC $(\%)$ & 45.6 & 50.3 & 23.2 \\
\hline pH Value & $3.2-3.8$ & $3.3-3.9$ & $3.4-4.3$ \\
\hline Specific Gravity $\left(G_{s}\right)$ & $1.08-1.35$ & $1.11-1.34$ & $1.25-1.67$ \\
\hline
\end{tabular}




\section{- Heat Treatment of Sarawak Peat}

The samples from four different locations in Kuching and Samarahan sites were dried at four different temperature for approximately 4 hours with various heat treatment of; $100^{\circ} \mathrm{C}, 200^{\circ} \mathrm{C}, 300^{\circ} \mathrm{C}$ and $400^{\circ} \mathrm{C}$, respectively. The temperature chosen was below $440^{\circ} \mathrm{C}$ as recommended by BS $1377: 1990$, if the temperature exceeds $440^{\circ} \mathrm{C}$; organic content in the soil will be burnt and thus gives significant affect to the moisture content value. Also, this heat treatment method is another approach for accelerating the preloading process of Sarawak peat. Reference [9] stated that this method provides time savings over conventional stress-induced pre-loading, thus, reduce stability issues associated with surcharging and offer a means of reducing the peat tendency for long-term creep.

The values for liquid limit for the treated samples shows decreasing due to the loss of organic content to hold the water in the soil. Samples that undergo heat treatment of more than $200^{\circ} \mathrm{C}$ are found not suitable to be tested for plastic limit test because the failure of the treated samples to be rolled into threads. The samples treated above $200^{\circ} \mathrm{C}$ can be categorized as non-plastic, NP and no liquid limit test required. This is due to the high amount of ash content caused by the burning of organic content of the Sarawak peat. A higher organic content is observed in the Sarawak peat with an increment of liquid limit. However, the values decreasing when subjected to an increasing of temperature from $100^{\circ} \mathrm{C}$ to $200^{\circ} \mathrm{C}$. The results are illustrated in Figure 2.

All the samples tested in their natural state give the values of specific gravity ranging between 1.08 and 1.67 . The values obtained are found to be in general agreement with [9], which stated that the specific gravity of solids in peat and organic soils is greater than 1 and increases with an increasing mineral content. However, once the Sarawak peat was treated with heat, the specific gravity was observed to be decreasing gradually with the increasing of temperature as plotted in Figure 3 .

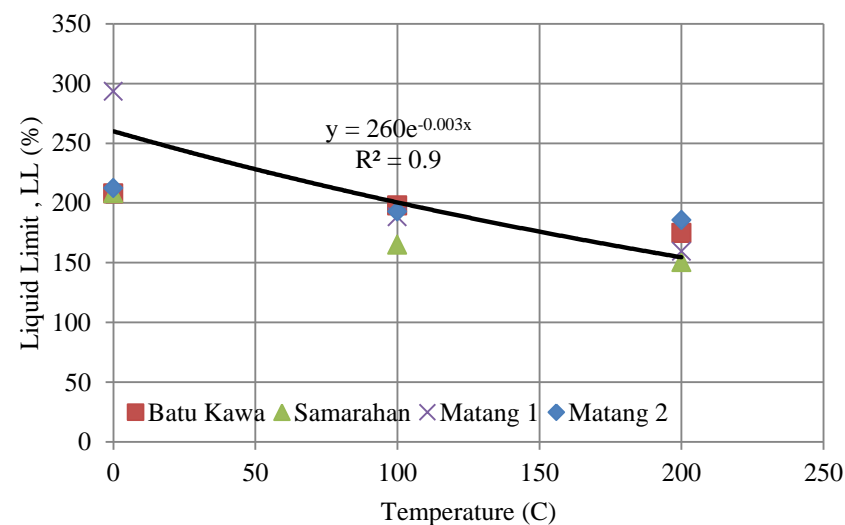

Figure 2 Liquid limit with temperature for Sarawak peat

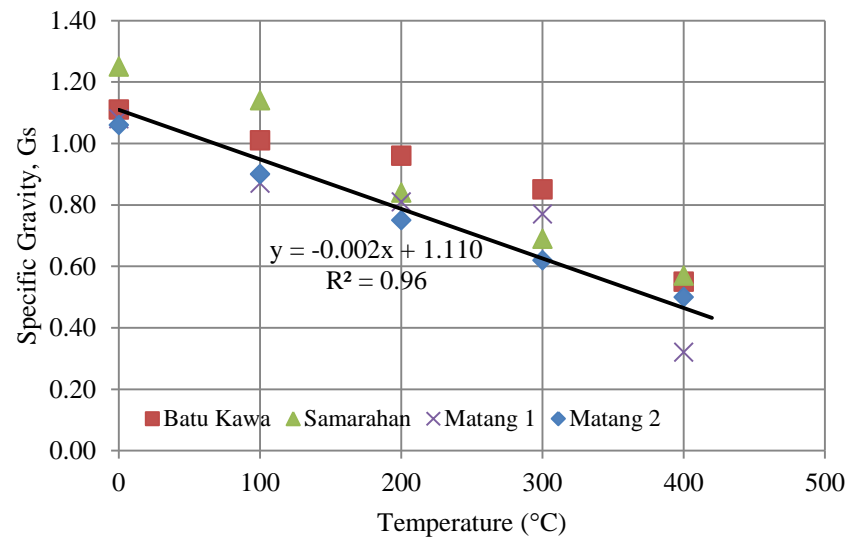

Figure 3 Specific gravity with temperature for Sarawak peat

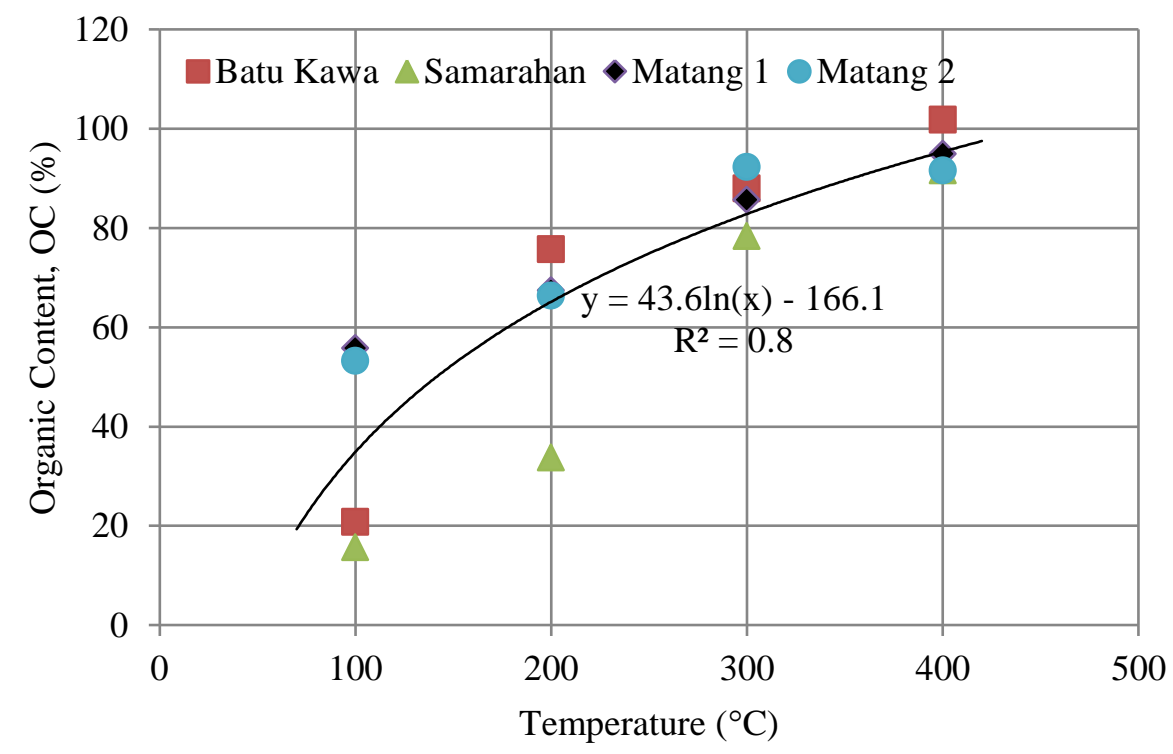

Figure 4 Organic content (OC) with temperature for Sarawak peat 


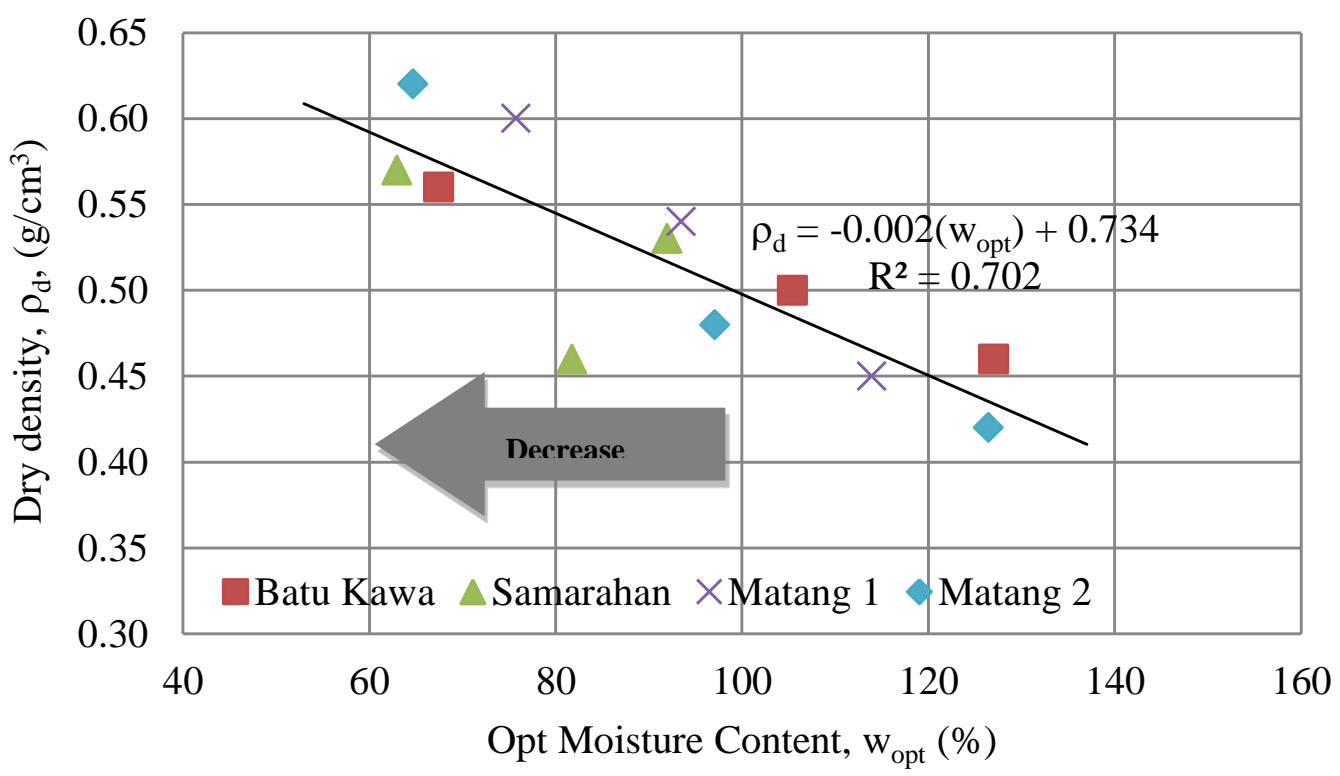

Figure 5 Dry density vs. Optimum moisture content for Sarawak peat

The organic content (OC) of peat is best determined from the loss on ignition (N). The equation by [11] is used to obtain the organic content of Sarawak peat. From the results obtained, the Sarawak peat has a high organic content of more than $90 \%$. The percentage of organic content as effect of heat treatment can be seen in Figure 4. An increasing of temperature up to $400^{\circ} \mathrm{C}$, the value for the organic content, (OC) also increases gradually, which caused by the increasing percentage of burnt compound in the samples.

The optimum moisture content and maximum dry density for Sarawak peat were obtained from the compaction test. The results show that the maximum dry density increases with decreases of the optimum moisture content. This relationship is clearly illustrated in Figure 5. The samples treated above $200^{\circ} \mathrm{C}$ were not tested as it was not suitable for the testing due to higher ash content. For treated sample, the dry densities are found to be higher than the original sample due to the loss of organic content when subjected to heat.

\section{EMPIRICAL CORRELATIONS OF SARAWAK PEAT}

Further analyses were performed by relating the results of the basic properties of Sarawak peat. This has been suggested by [12] that the convenient way is to relate the basic properties of soils to some of the easily determined index parameters such as water content, organic content or liquid limits. Figure 6 shows the relationship between the liquid limits with the moisture content for the current study and other published work. The liquid limit (LL) of Sarawak peat in this study was found to be about $0.33 w_{N}$, and the empirical equation could be written as in Eqn. (1). This empirical relationship obtained for Sarawak peat is lower than the fen peats reported by [12] where LL is about $1.18 w_{N}$. The [12] empirical relationship was in agreement with West peat (Selangor and Negeri Sembilan) however not for Sarawak peat. This may due to the percentage of peat fiber content in both locations; most of West peat is categorized under fibric peat (H1-H3) while the Sarawak peat falls under hemic types. Thus, higher empirical value for fibric peat is expected. Figure 7 illustrates the organic content with natural water content. The natural water content was found to range from $200 \%$ to $850 \%$ and with organic content varies from $78 \%$ to more than $95 \%$. The correlations of water content-organic content of Sarawak peat could be written; $O C=0.0074\left(w_{N}\right)+86$ as in Eqn. (2). The specific gravity of Sarawak peat ranges from 1.10 to 1.70. Figure 8 and Figure 9 showed the empirical correlation of the specific gravity $\left(G_{s}\right)$ between moisture content $\left(w_{N}\right)$ and organic content $(O C)$ of Sarawak peat with other published works. It is well determined that specific gravity of Sarawak peat decreases with an increasing of moisture content and organic content, respectively. However, the Sarawak peat has a different trend than that of the Selangor and Negeri Sembilan peats as it comprises only the Hemic group peat compared to the other two states, which consist of wider groups ranging from Fibric (H1-H3) to Sapric (H7-H10) peats. Both correlations could be determined by using Eqn. (3) and Eqn. (4), respectively.

- $\quad$ Liquid Limit-Moisture Content relationship,

$L L=0.33 w_{N}$

- Organic Content-Moisture Content relationship,

$O C=0.0074\left(w_{N}\right)+86$

- Specific gravity-Moisture Content relationship,

$G_{s}=0.19 \ln \left(w_{N}\right)+2.7$

- Specific gravity-Organic Content relationship,

$G_{s}=-2.36 \ln (O C)+12.14$ 


\section{UNIMAS e-Journal of Civil Engineering}

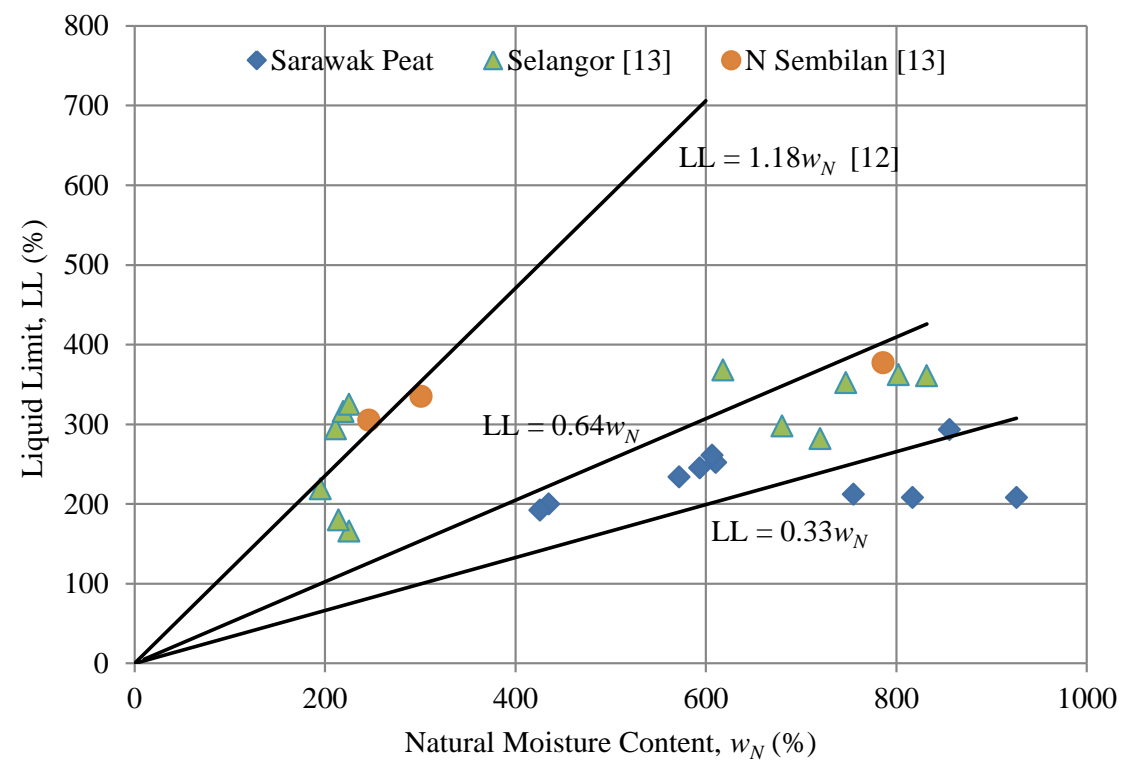

Figure 6 Moisture content - liquid limit correlations for Sarawak peat and other published works

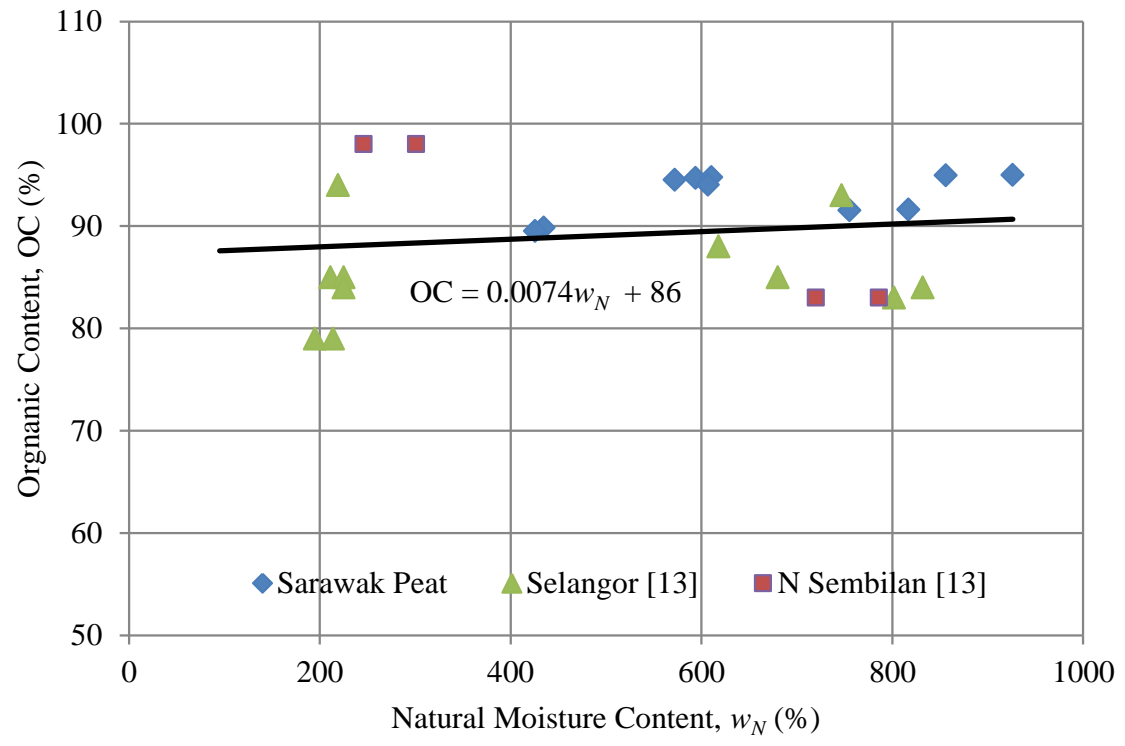

Figure 7 Moisture content - organic content correlations for Sarawak peat and other published works

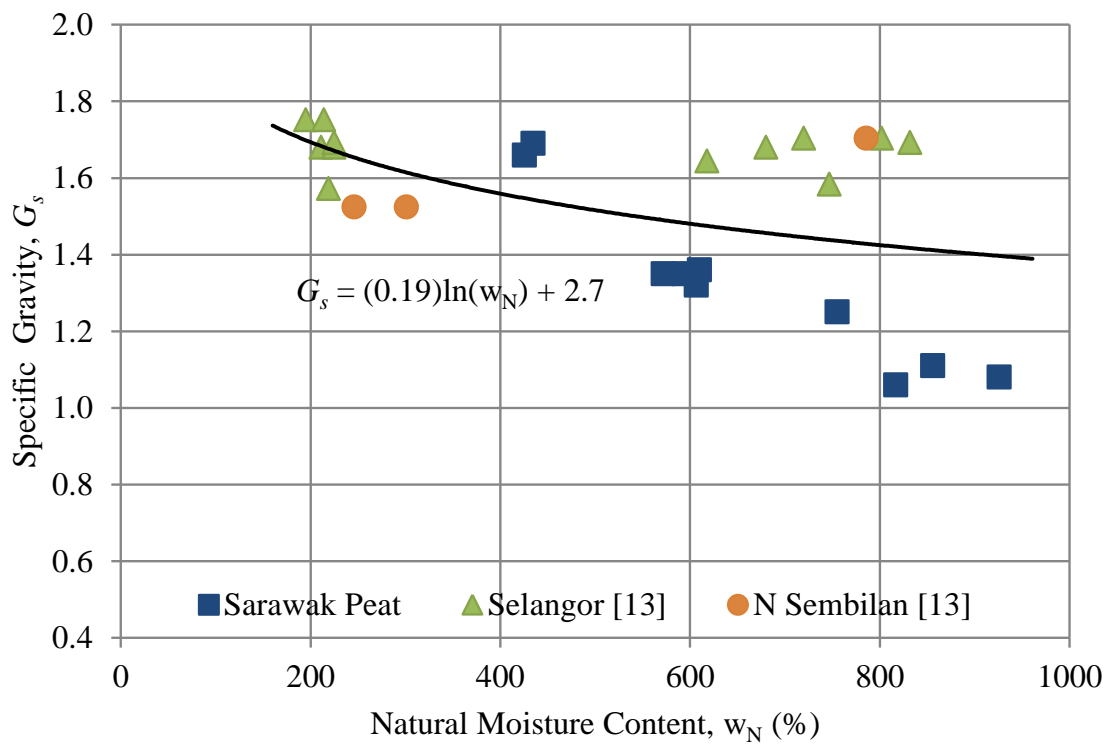

Figure 8 Relationship between moisture content and specific gravity for Sarawak peat and other published works 
The compression index, $\mathrm{Cc}$ is sometimes approximately estimated by empirical equations relating Cc to some simple index property of the soil. This compression index is determined and used for the estimation of preliminary settlement [14]. Many researchers [15] - [21] have presented the empirical models relating various index properties to the compression index. Some of the empirical correlations of compression index to various index properties are shown in Table 2 . The range of compression index that interest to know which, proposed by researchers are Cc values of 0.2 to 0.5 for normally consolidated, medium to sensitive clays, organic clays may have Cc values exceeding 4 and followed by peat with Cc values of 10 to 15 [19]. In this paper, an empirical equation proposed by [18] is chosen for determination compression index of Sarawak peat. The comparisons of compression index between non-treatments with heat treatment are tabulated in Table 3 and Table 4. Table 3 shows the compression index, Cc values for non-treated Sarawak peat varies from 5 to 11 . However, the results indicated that the heat treatment caused reduction in compression index, Cc of Sarawak peat significantly; with the value ranges from 3 to 4 (refer Table 4). This can conclude that, the compression index, Cc by heat-treatment is approximately 3 times compared with non-treated compression index rates.

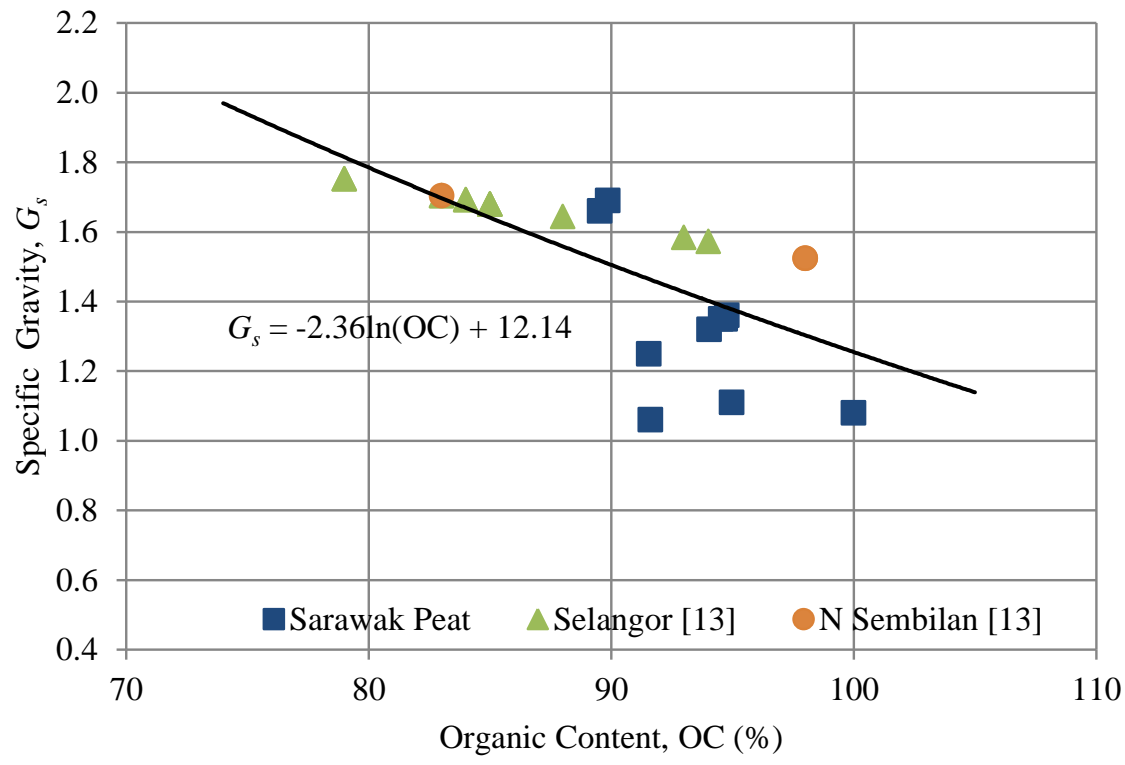

Figure 9 Relationship between specific gravity and organic content for Sarawak peat and other published works

Table 2 Some Empirical Models for Compression Index (Cc)

\begin{tabular}{clc}
\hline Empirical Model & Descriptions & Reference \\
\hline $\mathrm{Cc}=0.007(\mathrm{LL}-7)$ & Remolded clays & {$[15]$} \\
\hline $\mathrm{Cc}=0.009(\mathrm{LL}-10)$ & Undisturbed clays (low to medium sensitivity & {$[16]$} \\
\hline $\mathrm{Cc}=0.0115 \mathrm{w}_{\mathrm{N}}$ & Organic Soils and peat & {$[18]$} \\
\hline $\mathrm{Cc}=0.008(\mathrm{LL}-12)$ & Remolded soils & {$[19]$} \\
$\mathrm{Cc}=0.014(\mathrm{PI}+3.6)$ & & {$[21]$} \\
\hline $\mathrm{Cc}=0.332 \mathrm{LL}-0.390$ & Disturbed clays & \\
\hline
\end{tabular}

Table 3 Compression Index of non-treated Sarawak peat

\begin{tabular}{|c|c|c|}
\hline Sarawak Peat & Moisture Content, $\left(\mathbf{w}_{\mathbf{N}}\right)$ & Compression Index, Cc \\
\hline \multirow{2}{*}{ Matang 1 } & 594 & 7 \\
\cline { 2 - 3 } & 856 & 10 \\
\hline \multirow{3}{*}{ Matang 2 } & 572 & 7 \\
\cline { 2 - 3 } & 755 & 9 \\
\hline \multirow{3}{*}{ Batu Kawa } & 610 & 7 \\
\cline { 2 - 3 } & 607 & 7 \\
\hline \multirow{3}{*}{ Samarahan } & 926 & 5 \\
\cline { 2 - 3 } & 435 & 5 \\
\cline { 2 - 3 } & 426 & 9 \\
\hline
\end{tabular}




\section{UNIMAS e-Journal of Civil Engineering}

Table 4 Compression Index of heat-treatment of Sarawak peat

\begin{tabular}{|c|l|c|c|}
\hline Sarawak Peat & Heat Treatment & Liquid Limit (LL) & Compression Index, Cc \\
\hline \multirow{3}{*}{ Matang 1 } & Treated at $100^{\circ} \mathrm{C}$ & 188 & 3.7 \\
\cline { 2 - 4 } & Treated at $200^{\circ} \mathrm{C}$ & 159 & 3.1 \\
\hline \multirow{2}{*}{ Matang 2 } & Treated at $100^{\circ} \mathrm{C}$ & 193 & 3.8 \\
\cline { 2 - 4 } & Treated at $200^{\circ} \mathrm{C}$ & 186 & 3.6 \\
\hline \multirow{2}{*}{ Bt. Kawa } & Treated at $100^{\circ} \mathrm{C}$ & 198 & 3.9 \\
\cline { 2 - 4 } & Treated at $200^{\circ} \mathrm{C}$ & 175 & 3.4 \\
\hline \multirow{2}{*}{ Samarahan } & Treated at $100^{\circ} \mathrm{C}$ & 165 & 3.2 \\
\cline { 2 - 4 } & Treated at $200^{\circ} \mathrm{C}$ & 150 & 2.9 \\
\hline
\end{tabular}

\section{CONCLUSIONS}

The empirical correlations between organic content with natural moisture content, liquid limit and specific gravity of Sarawak peat are presented. The Sarawak peat consists of high organic content ranges from $89 \%$ to more than $95 \%$ with moisture content ranges from $426 \%$ to $926 \%$. Further comparison of compression index, Cc between non-treated and treated with heat treatment for Sarawak peat, the Cc values showed significantly reduction when subjected to high temperature. The $\mathrm{Cc}$ values obtained show an agreement with other published works. However, further laboratory and field investigation of peat throughout Sarawak are required for more comprehensive empirical correlation study on Sarawak peat.

\section{ACKNOWLEDGMENT}

The first author would like to thanks the technical staff for helping in collecting the peat samples. The Faculty of Engineering and Geotechnical Laboratory, Universiti Malaysia Sarawak (UNIMAS) for the resources provided. Also, for the scholarship granted by Malaysia government to the third and fourth authors. Finally, to those who are contributing directly and indirectly towards the preliminary study of Sarawak peat.

\section{REFERENCES}

[1] Melling, L., Ryusuke, H. and Mitsuru, O. (2002). Sustainable agriculture development on tropical peatland. $17^{\text {th }}$ WCSS, 14-21 August, Thailand

[2] Mutallib, A.A., Lim J.S., Wong M.H. And Koonvai, L. (1991). Characterisation, distribution and utilisation of Peat in Malaysia. Proceedings of the International Symposium of Tropical Peatland. 6-10 May 1991. Kuching, Sarawak, Malaysia.

[3] Singh H and Bujang B. K. Huat (2003), "Tropical peat and its geotechnics", $2^{\text {nd }}$ International Conference on Advances in Soft Soil Engineering and Technology, 2 - 4 July 2003, Putrajaya, Malaysia.

[4] Tai, L.Y., Lee, K.W., and Ting, W.H. (2003), "Some interesting aspects of peat formations in Sibu Town and related engineering issues.", $2^{\text {nd }}$ International Conference on Advances in Soft Soil Engineering and Technology, 2 - 4 July 2003, Putrajaya, Malaysia.

[5] Bujang B.K.Huat and Bahia, H.M. (editors) (1997). Proceedings of International Conference on Recent Advances in Soft Soil Engineering. pp.510.

[6] Huat, B.K., Asadi, A. and Kazemian, S. (2009). Experimental investigation on geomechanical properties of tropical organic soils and peat. American Journal of Engineering and Applied Sciences. 2(1); pp. 184-188.

[7] Edil T.B. and Fox, P.J. (1994), "Field demonstration of thermal precompression", Settlement 94, Special Conference of the American Society of Civil Engineers, Geotechnical Engineering Division, College Station, TX, Vol.2, pp.1274-1286.

[8] Fox P.J. (1992), "An analysis of one-dimensional creep behavior of peat", Ph.D Thesis, University of Wisconsin-Madison, USA, 245p.

[9] Edil T. B. (2003), "Recent advances in geotechnical characterization and construction over peats and organic soils", $2^{\text {nd }}$ International Conference on Advances in Soft Soil Engineering and Technology, 2 - 4 July 2003, Putrajaya, Malaysia.

[10] British Standard 1377: Part 2 (1990). Classification Tests. Soils for Civil Engineering Purposes.

[11] Skempton A. W., And Petley D. J (1970) "Ignition loss and other properties of peat and clays from Avonmouth", King's and Lynn \& Cranberry Moss, Geotechnique, Vol.4, pp. 343-356.

[12] Hobbs N. B (1986). "Morphology and the properties and behaviour of some British and foreign peats", Quarterly J. of Engineering Geology, London 19: pp. 7-80.

[13] Al-Raziqi A. A., Bujang B. K. Huat \& Munzir H. A (2003), "Shear strength parameter of some organic soil", $2^{\text {nd }}$ International Conference on Advances in Soft Soil Engineering and Technology, 2 - 4 July 2003, Putrajaya, Malaysia.

[14] Ranjan, G and Rao, A.S.R. (2005). "Basic and applied soil mechanics", $2^{\text {nd }}$ ed. New Age International (P) Limited, Publishers, New Delhi, India.

[15] Skempton, A. W. (1944). Notes on the compressibility of clays. Q. J. Geol. Soc. London, 100(1-4), pp. 119-135.

[16] Terzaghi, K. and Peck, R. B. (1967). Soil mechanics in engineering practice. John Wiley, London.

[17] Wroth, C. P. and Wood, D. M. (1978)."The correlation of index properties with Some Basic Engineering Properties of Soils." Canadian Geotechnical Journal, 15, pp. 137-145.

[18] Bowles J.W. (1979) Physical and geotechnical properties of soils, McGraw Hill, New York.

[19] Sridharan A., Nagaraj H. B., 2003, Coefficient of consolidation and its correlation with index properties of remolded soils. Geotechnical Testing Journal, Vol. 27, No. 5 Paper ID GTJ10784. Available online at: www.astm.org.

[20] Tiwari, B. T. and Ajmera, B. (2012). New correlation equations for compression index of remoulded clays. J. Geotech. Geoenviron. Eng., 138(6), pp. 757-762.

[21] Hong, Z. and Onitsuka, K. (1998). A method of correcting yield stress and compression index of Ariake clays for sample disturbance. Soils and Foundations. Vol. 38. No. 2. pp. 211-222. 